\title{
Perspectives on \\ Iowa: The Middle Land: \\ A Book Forum
}

Iowa: The Middle Land, by Dorothy Schwieder. Ames: Iowa State University Press, 1996. xvi, $381 \mathrm{pp}$. Maps, illustrations, notes, note on sources, index. $\$ 42.95$ cloth, $\$ 24.95$ paper.

\section{EDITOR'S INTRODUCTION}

The long-anticipated publication of Iowa: The Middle Land represents a landmark for the cause of Iowa history. About twenty years ago, two distinguished scholars published one-volume surveys of Iowa history: Leland Sage's A History of Iowa (1974) and Joseph F. Wall's Iowa: A Bicentennial History (1978). Whatever the relative merits and demerits of those two books, much Iowa history research has appeared in the intervening years. That research has significantly increased the base of knowledge about previously little-known areas, such as women's, labor, urban, and ethnic history, and has raised new questions and used new methods in the study of more traditional topics, such as agricultural and political history. This new knowledge has refined - and at times necessarily complicated-our understanding of Iowa's past.

In writing Iowa: The Middle Land, Dorothy Schwieder has taken advantage of that generation of research, as well as her own extensive experience in synthesizing that material in the course of teaching Iowa history for twenty-five years at Iowa State University. But the book is written not only, or even primarily, for people familiar with that new scholarship. It is, in

THE ANNALS OF IOWA 55 (Summer 1996). CThe State Historical Society of Iowa, 1996. 
fact, designed to mediate the latest and best interpretations of Iowa history to a variety of audiences. To acknowledge that goal - and to assess how well the book achieves it-I asked representatives of several different potential audiences to review Iowa: The Middle Land on behalf of a specific audience. The result is this forum.

What kind of book is this, and what kind of experience does an author bring to such an enterprise? James $H$. Madison, the former editor of Indiana's state history journal and a veteran of producing a similar history of Indiana (The Indiana Way: $A$ State History [1986]), introduces us to the genre and the authors who shape it, then assesses how Iowa: The Middle Land measures up. Barbara Handy-Marchello, a rural social historian from the University of North Dakota (with a Ph.D. from the University of Iowa), provides a concise summary of the contents of the book and comments on its contribution to our understanding of several broad historical themes that played key roles in the state's development. Handy-Marchello praises Schwieder's success in writing a book "in which the voices of Iowans contribute directly to an understanding of historical events." Richard, Lord Acton, a relative newcomer to the state, picks up that theme and illustrates it with engaging quotes from everyday people that he found in the book. Those voices, he insists, will delight other newcomers to the state's history. At the same time, he says, the insights the book offers will stimulate and educate readers of all sorts.

Three reviews for more specialized audiences round out the forum. Public historian Jan Nash (of Tallgrass Historians L.C.) describes the uses and limitations of the book for public historians in lowa and the Midwest. In addition, she alone raises a significant caution that the driving concept of the book, Iowa as "the middle land," "may lead researchers to facile and less than satisfying conclusions." The final two reviews evaluate the book's usefulness for history educators. Lynn Nielsen, professor of education and director of Price Laboratory Schools at the University of Northern lowa, argues that Schwieder's excellence at modeling the craft of writing history and at selecting and organizing the content of that history promise to indirectly help elevate the level of Iowa history instruction in Iowa's elementary, 
secondary, and continuing education classes. Finally, the most specialized audience of all, but one especially dear to Dorothy Schwieder and, in fact, much of the impetus for the book, comprises students and teachers in college or university courses in Iowa history. Wallace Hettle, who teaches Iowa history at the University of Northern Iowa, joins his colleague Lynn Nielsen in affirming the value of Iowa: The Middle Land for engaging students in the process of fitting together the diverse materials that make Iowa history.

Together, these reviewers affirm that the publication of Iowa: The Middle Land is a landmark event for Iowa history. But they would probably also agree that it is not the last word. As James H. Madison concludes, "Other Iowa historians will continue to build the research base, and in a couple of decades one of them will provide a one-volume survey for that generation, building on Schwieder's work just as she has built on that of Leland Sage and many others." That base has several legs, as Schwieder herself points out in her preface (and as Richard, Lord Acton reminds us). Those legs are represented by several significant Iowa history books published within a year of Iowa: The Middle Land. Readers should check out, for example, the reviews in this issue of the Iowa History Reader, edited by Marvin Bergman (1996); Legislators and Politicians: Iowa's Women Lawmakers, by Suzanne Schenken (1995); and the cowinners of the 1996 Benjamin Shambaugh Award for the most significant book on Iowa history published during 1995, To Go Free: A Treasury of Iowa's Legal Heritage, by Richard, Lord Acton and Patricia Nassif Acton, and Smith Wildman Brookhart: Iowa's Renegade Republican, by George McDaniel.

\section{JAMES H. MADISON}

Dorothy Schwieder's new history of Iowa joins a shelf full of similar histories of other states. These one-volume surveys provide an overview from prehistoric times to the present, usually chronologically organized, and with a content and style designed to meet the needs of diverse readers, from college students in state history courses to interested lay readers to scholars seeking the context for a particular subject of research. 
The most successful of the recent state histories share several characteristics. They are built on a large research base, far deeper than suggested in the usually brief endnotes and bibliography. That research is almost always centered in the scholarly state history journal, where dozens and dozens of pioneering articles on all manner of subjects appear over several decades. And there are always a few dozen key monographs, some recent, some fifty or more years old, books that critically inform the one-volume survey.

The authors of the best of these state histories are not mere distillers of this vast scholarly literature. They are practicing scholars themselves, historians who have worked deeply in the primary source material and have created new knowledge about their state. Many are generalists who have published on all manner of subjects connected to the particular state. Many are college history teachers, with years of experience teaching a state history course, wherein they learn as much about the state as they do in the library and archives, especially about framing the large issues and organizing them so as to communicate clearly and effectively to inexpert audiences. These state history authors actively live in their particular state: they know its present-day politics and culture; they have seen its county courthouses (probably every one of them); they are all too well acquainted with the interstate highways and the McDonalds; and they are familiar with the back roads and the mom and pops. They have spoken to Rotary Clubs, alumni clubs, and many of the county historical societies as well as the meetings and workshops of the state historical society and humanities council. They cannot resist the temptation to apply labels to the state's people, terms like moderate, friendly, commonsensical. And despite all this local activity, they remain connected to the larger historical profession. Cosmopolitan and comfortable outside their state, they remain convinced nonetheless that state boundaries are important and essential parts of our past and future. Though sometimes impatient, even angry, with their particular state in areas such as laggardly support of education (though Iowans have less to gripe about there than most other Americans), state historians are among their states' most genuine boosters. Especially to outsiders from other states, they are quick with reasons why 
their state is different from the other forty-nine and also like the rest of the nation. Seldom do they argue that it is better than other states. That secret they keep to themselves.

In many ways, Dorothy Schwieder and her book, Iowa: The Middle Land, fit this profile of the genre of one-volume state histories and their authors. And her book shows magnificently the strengths of the best of the genre. Iowa is a state with a rich scholarship. Schwieder herself has contributed to that base in her research and publications on mining communities, the Old Order Amish, cooperative extension, and women, in her teaching at Iowa State University, and in her active participation in the profession in Iowa and the nation.

Iowa: The Middle Land shows not only the strengths of the best of recent scholarship in history but connects that scholarship to the general reader. Schwieder lays out large generalizations and broad contexts on all manner of subjects, but she carefully includes real people as examples and illustrations of the larger issues. Particularly outstanding is her ability to include women and African Americans in her narrative, not tacked on as afterthoughts, but integrated into the central themes and issues. More than most state histories, this one brings to fruition the results of social history as practiced over the past three decades (perhaps fitting since major parts of that social history were pioneered at the University of Iowa, where Schwieder earned her Ph.D.).

Schwieder has successfully met the state historian's challenge of bringing people into the story. She has also met the challenge of covering the diversity of places and groups that characterize any state's history. She shows the geographic and cultural diversity of a state that outsiders regard as homogeneous. She presents the towns and cities in the framework of the state's past, and she introduces the variety of immigrant and ethnic groups, the religious denominations, and the social organizations that are central. This she achieves without the kind of boring roll calls that tempt lesser writers.

No one-volume state history pleases all readers all the time. Some readers will wish the book's illustrations appeared in larger and clearer reproduction. Some will wish for more maps: there is, for example, no map of railroad lines, and the few maps 
that are included, such as the one on page 241, have county labels that are too small to read. Perhaps the most common lament state historians hear is that some thing or other is left out of the book. When what is left out is a reader's great-grandfather who fought at Pea Ridge, the state historian listens and smiles patiently. When it is a larger issue and the critic is knowledgeable, the author listens carefully, takes notes, thinks of a second edition, or simply responds that she has a different kind of book in mind.

What might friendly critics say of Iowa: The Middle Land? Some will note that this is history without the politics. Schwieder tells readers in the preface that her emphasis is on social history because it has been so "badly neglected, whereas political history has been amply treated, particularly by Leland Sage in $A$ History of Iowa" (xiii). But that will not help the reader who will have the time and interest to read only one history of Iowa. More important, this issue of emphasis raises the question of what state history is and what a state is. Although there can be many compelling answers, it must be acknowledged that states are political and governmental units and that as such they have had and still have critically important functions in such areas as education, taxation, environmental protection, and social welfare. Many Americans do not understand the varied and key roles of states, the many ways they affect our lives as political and governmental units. Because of Schwieder's emphasis on social history, she sometimes misses opportunities to educate readers on that point.

Another issue that some readers will miss is corn. The book's cover features an Iowa corn field front and center, but Schwieder pays only scant and indirect attention to corn. There is a lot to be said about corn, as John Hudson's book, Making the Corn Belt (1994), demonstrates. Schwieder's index has an entry for coal mining but not corn. The only entry for corn in the index under agriculture refers to the "corn-hog complex," but the office worker in Des Moines will not understand this critically important part of Iowa's history from Schwieder's oneparagraph description. Nor will readers understand the human meaning of the long weeks spent husking corn by hand or the lonely hours spent driving that expensive machine through the fields. 
Finally, some critics will charge that lowa: The Middle Land ends with a whimper. Schwieder devotes far less space to the years since World War II than other comparable periods of time. Many readers will want to know more about this recent past, particularly college students who don't remember a time without Wal-Marts or MTV. They need to know how the late twentieth-century trends toward homogenization have affected Iowa; they need to know about schools and social welfare, about recent efforts to diversify the economy and attract new industries, an area in which state and local governments have made huge and sometimes unwise investments. These readers will wonder why the Iowa caucuses get so much attention at presidential primary time, and what image of Iowa is held by outsiders in the late twentieth century. And they will want more generalizations about the "Hawkeye character" and perhaps some reconciliation between those generalizations and the state's descent into the abyss, or rise into the heights, of gambling. (Does free day-care in a gambling venue adequately address family values?) Schwieder touches on many of these issues, particularly gambling. And she faces the same challenges other state historians have faced. She is hampered by the paucity of useful analytical studies (because our scholarly colleagues in the social sciences have too often abandoned state-level analyses of contemporary issues). And, of course, there is not the historical perspective on the late twentieth century that there is on the late nineteenth. Schwieder's response to these challenges of recent history is as good as and perhaps even better than most state history volumes. But it is an area in which the field needs to do better.

Each reader will have a list of things missing from this onevolume survey. (I'd like her to fit into the narrative the Hawkeye expatriates in southern California and their Long Beach picnics, as well as the more recent communities in Arizona.) But what is missing is not nearly as important as the many things that are there. Above all, there are the people. Schwieder has assembled them in a narrative history that is well organized and well written, that conveys the changes and the continuities that make Iowa a place with a distinctive identity. Many proud Hawkeyes will be able to see in this one-volume history their 
roots and their centeredness in the middle land. Other Iowa historians will continue to build the research base, and in a couple of decades one of them will provide a one-volume survey for that generation, building on Schwieder's work just as she has built on that of Sage and many others. That next generation will have a high standard.

\section{BARBARA HANDY-MARCHELLO}

Dorothy Schwieder has written a well-balanced and wonderfully readable history of Iowa. Noting that previous Iowa histories have successfully focused on political events, Schwieder wisely chooses to use her strengths in social and economic history to write a book in which the voices of Iowans contribute directly to an understanding of historical events. The words of governors and miners, farmers and Mesquakie lend this book a warmth and liveliness unusual for a state history.

Schwieder attends well to the business at hand. She covers Iowa's history thoroughly, beginning with the earliest records on the Indians of the area and carrying through to the 1990s. Dividing the book into three time periods, she follows the threads of social, economic, and, to a lesser extent, political developments through each section. The time periods are a little awkward and lack well-defined dates, but are still useful in providing a framework for events. There seems to be little evidence for her decision to use 1870 as the approximate end for the frontier era in Iowa, but it works well enough. Schwieder seems to be caught between a traditional format, which usually links historical events and processes to decades or centuries, and recent challenges to tradition which cite the inadequacy of the calendar as a demarcation device.

Schwieder outlines the history of Indians in Iowa, focusing on their relationships with European-Americans. The Ioway dominated the area in the eighteenth century, but they were crowded by the Sauk and Mesquakie as those tribes were driven west by settlement in Illinois and Wisconsin. Ultimately coerced by the United States government, the Ioway moved to a reservation in Kansas. Sauk and Mesquakie agriculture and lead mining attracted traders, soldiers, and miners to the area in trade and 
competition. Treaties, unreliable agents, and traders depleted their wealth. The Indian Removal Act of 1830 finally forced the Sauk and Mesquakie out of Iowa, although the Mesquakie returned in 1856 to buy the land where they remain to the present.

Indian removal opened the area for European-American settlement. Most of the earliest settlers were people who moved into the prairies of Iowa from states to the east. Iowa, Schwieder points out, was the "transition zone between timbered regions to the east and the vast plains area that lay to the west" (36). Here pioneers learned to live in the grasslands. Although some painfully missed trees, towns, and near neighbors, others found the quality of the soil and the absence of tree stumps promising.

Iowa's population would remain rural and agricultural until the 1950s, but town development proceeded quickly during the early years of settlement. The first towns grew up along the Mississippi River and later along other major rivers. Rivers provided transportation for newcomers coming into Iowa and for products shipped to St. Louis. A new era in Iowa's economy followed when railroads entered the state in the $1850 \mathrm{~s}$, sometimes bypassing the river towns and drawing trade toward Chicago. Railroads meant better access to markets for farmers and allowed for the growth of small towns along the lines, but created an uncomfortable dependence for towns and farmers.

Iowa's economic growth had two solid foundations: agriculture and industry. Schwieder gives equal treatment to both parts of the economy and demonstrates the close ties between them. The farm economy fostered much of the early industry such as meatpacking plants and farm implement manufacturing. Mining had a brief but important impact on the state's economy and culture. In the twentieth century, manufacturing expanded into areas not associated with agriculture, while farming continued to be an important occupational category and economic base. Farming's continuing impact on the state's economy, social structures, and politics was apparent during the crisis of the 1980s. Schwieder deftly and gently describes the farm crisis in human terms, bringing the book to a close with some uncertainty about the future of farming in Iowa.

Schwieder brilliantly weaves together cultural and economic history, illustrating the complex texture of life within the various 
segments of Iowa's economy. Workers are real people whose opinions about their work reveal a lot about the quality of life in Iowa. And the qualities of their lives are intimately tied to the work they do. Meatpackers often were new immigrants who lived near the stockyards in parts of town neglected by city improvements. The Inspirationalists' faith, along with a history of skilled work and communal living, led to the development of the Amana Colonies and eventually the Amana industries. Immigrant women were suspicious of the modern equipment in a public laundry, fearing that it signified that women were becoming too weak to wash by hand. With carefully selected examples and quotations, Schwieder demonstrates the link between culture and work.

Schwieder integrates women's activities, both daily and exceptional, into the patterns of Iowa's history. The everyday work of farm women merits full attention. The dollar value of farm women's productive work ( 30 percent of farm income in 1933) suggests that butter and egg income amounted to a good deal more than "pin money." Women's work in nonfarm jobs also contributed to Iowa's economic growth. As early as 1870 , women held 6 percent of Iowa's jobs. By 1990, more than 40 percent of the work force was female. Women also proved an important force for social change, operating settlement houses in Des Moines and other cities and focusing the state's attention on prohibition and woman suffrage. Schwieder describes the important work of nuns in establishing schools and a facility for the mentally ill, but neglects the work of Protestant women's organizations in shaping their communities.

Schwieder has chosen an appropriate concept for this history: Iowa is a middle land, not only geographically, but in the American mind. At the same time, she never leaves Iowa isolated between the rivers, but connects the state to cities and states to the east and the west through its people and products. Iowa is also temperamentally a middle land. Extremes of thought and behavior are so rare as to require special attention and explanation when they occur. As she demonstrates the ways Iowa's story is embedded in national events and historical patterns, Schwieder shows how Iowa is often seen as a measuring stick for national concerns and changes in social and economic cus- 
toms. This is the middle America that national newscasters so fondly court. This is the location of the "typically American" anything. So when something goes wrong in Iowa, such as the farm economy, it draws the attention of the nation out of concern for itself.

This is not to say that Schwieder has sugar-coated Iowa's history. She maintains a careful balance between Iowa's strengths and its dark side. We read that the Ku Klux Klan had a stronghold in Greenfield. A Methodist minister was assassinated in Sioux City while campaigning for prohibition. Racial discrimination against African Americans and Asians limited their ability to contribute to the state's growth. Schwieder reminds us that social change comes slowly and generally at great cost to someone. She also suggests that economic distress could (and did) create rifts in Iowa's social landscape. More subtly, Schwieder weighs the costs of rural and small town life-stifling social rigidity - against the comfort of an orderly society.

Iowa: The Middle Land has a few, small, black-and-white photographs. Because the photos are well chosen, readers may wish for more. The preface contains a good map, and a few special topic maps appear in the text. The endnotes provide an excellent resource for further reading in Iowa's rich historiography and on related national topics, but a bibliography would have made the selection of further reading materials easier.

Dorothy Schwieder's history of Iowa shares the shortcomings of every book that tries to cover a lot of time, space, and topics in three hundred pages. There isn't room for everything. But Schwieder offers the serious student a firm footing from which to explore further questions about Iowa's social and economic history, the tools with which to begin the research, and a fine model for integrating the social, economic, and political aspects of life in the Middle Land.

\section{RICHARD, LORD ACTON}

Until Dorothy Schwieder's book came out, only two modern single-volume books existed to which a lay reader with an interest in Iowa history would naturally turn. Leland L. Sage's History of Iowa (1974) is primarily political; although invaluable, 
it is both limited in scope and heavy going. Joseph F. Wall's Iowa: A Bicentennial History (1978) is much easier to read, but is really a series of essays rather than a continuous history. Now comes Schwieder's fine work on Iowa's social history. Her book is thoroughly readable, and a newcomer to the subject will find it highly informative and enjoyable. In' 325 pages, the author tells the social history of Iowa, starting with a chapter on Native Americans and going right through to the 1990s. She has set herself a daunting task and pulled it off with praiseworthy skill.

The author enriches her book by drawing on a multitude of secondary sources. The endnotes and the note on sources demonstrate the great breadth of Schwieder's scholarship. She gives the impression that she knows by heart the whole of the Annals of Iowa and the Palimpsest, as well as innumerable books and theses. Yet she has succeeded in boiling down this vast mass of material into a remarkably manageable book.

A particularly commendable feature is that Schwieder cites the names of many authorities in the body of the text itself. This leaves the reader in no doubt that in those instances, the author is not pretending to express a view of her own. Moreover, if the reader has a keen interest in some subject-say, early African-American history-he or she doesn't have to thumb to the back of the book to learn that the works of Robert Dykstra and Leola Nelson Bergmann are vital authorities.

Schwieder is especially good at picking out striking quotations, filling her narrative with life. She quotes a pioneer woman in the mid-1850s, looking at the prairie in Marshall County and whispering to her husband, "There are no trees, Ryal. I shall die of it" (38). Another pioneer woman wrote, "I did all the washing by hand, rubbing every garment, and often stood on one foot while rubbing and rocking the baby's cradle with the other foot to keep her from waking up" (49). A Lutheran minister said of the 1880s, "One may live for months in Elk Horn without needing to use any language other than Danish" (101). A farm woman in the 1930s wrote to Wallaces' Farmer that the coming of electricity was like having a "houseful of servants servants that carry water, sweep rugs, help with washing and ironing and preparing of meals" (273). Schwieder's technique of giving such individual examples not only makes her book 
hum; it can also shed new light on a subject. Discussing social life before World War I, she quotes Winifred M. Van Etten, who grew up in Emmetsburg: "No nice girl had a dog of her own. The family dog was all right, but as a piece of personal property the dog was taboo" (160). The changing social status of the personal pet came as an intriguing surprise to this reader.

In addition to providing an outstanding picture of everyday life-particularly of women's lives - cultural diversity is a strong suit of the book. The story of Luigi Jacopetti, who arrived in Des Moines from northern Italy in 1880 and ran a shop where he sharpened scissors and knives, gives the reader a real feel for the life of immigrants. So does the experience of the Swedish-speaking Erickson family, who after 1900 worked in the coal mines and company store of Buxton and took in boarders. The description of the "Turnfest" in Dubuque in 1873, with its gymnastic competitions, choral clubs, bands, marches, and speeches, vividly illustrates how German immigrants brought their culture with them. In Davenport, a German immigrant mother, upon greeting her son who had returned from Cornell University, was appalled to find that he hadn't been able to afford beer there. As soon as they got home, she "ran into the kitchen and brought out a bucket of beer and a steaming dinner of sausage and sauerkraut" (96). You can almost taste the meal.

The newcomer to Iowa history will be interested in the story Schwieder tells of African Americans in the state. For example, a black woman, Marjorie Brown, called the Great Depression "one of the bitterest periods of my life. ... I'm one of the people who ... watched the house full of furniture be taken to be reclaimed.... I have worked seven days a week doing housework, and that includes washing, ironing, and cooking - and believe me, we did do windows - for five dollars a week" (268). The sagas of the Amana Colonies, the Old Order Amish, and the Mexican Americans in Bettendorf are all admirably told.

One limitation of basing the work to such an extent on secondary sources is the sort of gap the author points out when she writes, "Unfortunately there has been little research done on Russian immigrants in Iowa" (189). However, later we do learn that Russian immigrants played a vital part in organizing unions in the Sioux City meatpacking houses during the 1930s. 
So rich is Schwieder's book that it is difficult to choose its greatest strengths. Certainly the contrast between rural and urban life is outstanding, as are her treatments of immigration, coal mining, education, religion, and the endless battles over alcohol. The fifty-year period since World War II is well handled but brief. Schwieder explains in her preface that the last chapters are less developed than the earlier ones "because little scholarly work has been done on topics in Iowa history since the 1930s" (xiii). As it is, her succinct summary of the past half-century is first rate. For example, she describes legislative reapportionment after World War II so well that for the first time I understood that fiendishly complicated subject.

Excellent though this book is, there is the occasional minor error. For example, the author reiterates Joseph Wall's mistake that six Iowans accompanied John Brown to Harpers Ferry, when in fact only four went. Mysteriously, the book describes Napoleon as ruling France in 1762, whereas Napoleon was not born until 1769. In this instance, the gremlins have run amuck.

There are also, of course, those topics that individual readers will wish had been treated more fully. I would have welcomed more about rural and urban children's lives. Other readers may wish to learn more about the role books, newspapers, and libraries have played in Iowans' lives. Readers fascinated by things military may long for more than fifteen pages on the Civil War era. The crucial subject of the effect of television has only a short mention, and sport-which is important to so many Iowans - receives only scant attention. But an author seeking to cover the whole social history of Iowa in 325 pages simply cannot be expected to include everything, and in chapter after chapter, Schwieder has achieved a remarkable, compressed social history. Readers who want to follow up on the Civil War or any other topic covered by the author will find that the endnotes and note on sources point the way.

In her preface, Schwieder describes how Leland Sage, in the introduction to his History of Iowa, encouraged historians to "give Iowa a storehouse of information worthy of the stamp of History" (xiv). Sage called for the writing of several singlevolume histories, then a multiauthor dictionary, and finally, a multivolume history of the state. Humbly, Schwieder writes 
that she hopes "that the present volume will contribute to the process" (xiv). Iowa: The Middle Land is a magnificent contribution to Sage's dream pyramid. This work is so engagingly written that it will delight, stimulate, and educate any lay reader who wanders into a book shop or library looking for something to read about Iowa history.

\section{JAN NASH}

For public historians, the 1996 sesquicentennial anniversary of Iowa's statehood was just cause for celebration, a year-long birthday party to which Dorothy Schwieder brought one of the best gifts. Iowa: The Middle Land adds to the reference shelf a comprehensive yet concise discussion of the diverse historic events and trends that over the past 150 years have made the state what it is. The book is a synthesis of the important studies of Iowa history that preceded it, but broadened with newer work in social and cultural history, labor history, and minority and women's studies, and updated with chapters on Iowa's recent past.

Professionally trained historians working outside the university setting - for local, state, and federal agencies or historical societies or as cultural resource managers, museum curators, librarians, or archivists - constitute a bridge between the academy and lay audiences. Their goal is to interpret and effectively communicate the history of a site, person, or event in a format tailored to a specific public group. Members of the public historian's audience - and their reasons for listening - can be quite dissimilar, ranging from a group of 12-year-old school children touring a local historic site to an urban planning director trying to field questions from both irate neighborhood residents and the real estate developer who just demolished one of the neighborhood's gems. Public history is typically multidisciplinary, often performed as a team effort, and usually bounded by welldefined deadlines and budget considerations. The public historian's work may be published as a museum exhibit, a National Register of Historic Places nomination, a documentation plan intended to mitigate the loss of a historic building, or a video 
documentary such as this year's Iowa: An American Portrait broadcast by Iowa Public Television.

Historians working on such projects necessarily rely on both academic publications and their own research into primary materials such as diaries, courthouse records, and oral histories as well as, very often, the careful examination of a physical landscape, building, or artifact. For example, the historic site manager of a lavish nineteenth-century Italianate dwelling built by a railroad magnate interprets this artifact by studying the building itself to determine architectural style, historic construction techniques, and spatial functions. However, the building's interpretation also rightly includes cultural, economic, and labor history to explain how a few individuals prospered so greatly, why these individuals displayed their economic status in such a conspicuous fashion, and how their wealth influenced the lives of family members and domestic employees of the household. Explaining the methods and the full impact of the accumulation of such wealth to modern audiences - in this case probably heritage tourists - enhances the interpretive value of the house as an artifact and justifies the expenditure of limited resources to preserve it.

Iowa: The Middle Land adds a new tool to the reference shelf for the novice public historian who may not need to delve deeply into any one aspect of Iowa history. The book's broad-brush treatment of state history, together with its references to more specialized sources, orients such a historian and points in the direction of additional research. The book is also well suited for those engaged in history-related activities, such as the archivist or librarian who needs general knowledge but not detailed expertise on the whole array of Iowa history subjects. Iowa: The Middle Land does not, however, attempt to give the seasoned practitioner of public history much in the way of new interpretive material. Instead, Schwieder draws heavily on such acknowledged standards as Leland Sage's political history of the state, the diverse subject matter addressed by William J. Peterson, and Earl D. Ross's economic analysis of Iowa agriculture. The author also incorporates newer work in social history, ethnic and minority history, and women's studies; for example, she uses her own study of the largely African-American min- 
ing community of Buxton and Robert Neymeyer's research on Waterloo's early twentieth-century black community to update and add depth to Leola Nelson Bergmann's account of AfricanAmerican Iowans first published in 1948.

The diversity of the author's source material is impressive, ranging from secondary literature to unpublished papers to diaries and recent newspaper articles, and gives the researcher a taste of the full assortment of material available. Schwieder makes good use of the state's popular history magazine, the Palimpsest (now called Iowa Heritage Illustrated). Indeed, Palimpsest articles are used effectively to personalize historic events or localize broader trends. Occasionally, however, popular history articles are used in lieu of the underlying original research publications, leading to a restatement of a restatement and leaving a difficult trail to follow for readers wanting more detail. The discussion of Iowa's territorial period and its first governor, Robert Lucas, for example, does not refer to either Lucas's detailed biography or any of the more recent scholarly work prompted by the restoration of the territorial capitol in Iowa City. It may well be that these sources were not overlooked by the author, but the lack of a bibliography makes it impossible to know.

Indeed, those looking for an extensive bibliography will be disappointed. The decision not to include one is a missed opportunity to make the book more useful. Without a bibliography, the book is cumbersome to use as a reference work, and its readers are denied access to the entire body of research Schwieder used. Although the author does briefly annotate her major sources in a "note on sources," committed students of Iowa history will already be familiar with most of the publications cited and may have many of them in their bookcases.

For the new researcher embarking on a study of the state's history, the "middle land" context embedded in the title of the book and set up within its first few pages is a tempting and ready filter through which to view the state or the region. Iowa's location in the middle of the Midwest places it inevitably in the middle of the nation. Not just geographically centered, Iowa is also the environmental middle ground between the forests of the East and the Great Plains shortgrass prairie. Originally 
settled by Native Americans who mixed a mobile hunter lifestyle with more fixed agrarian ways, the land later was taken over by European-Americans who meshed industry with agriculture. This middling status of geography, environment, and lifeways, Schwieder concludes, is also useful for understanding Iowans as individuals: "Certainly there is a sense of moderation in the way people have lived. There is a sense of rootedness in the state that implies stability, permanence, and continuity; there is also a sense of centeredness that connotes balance. . . . people tend to be ... accepting of the status quo, and not given to wide swings of emotions or erratic behavior" (xi-xii).

This middle land context has the effect of defining Iowa by what it is not, rendering it the status of a sort of back door to the East or front door to the West. As the discussion of what constitutes the Midwest and whether or where it fits into the study of western history gains momentum, this middle land context may lead researchers to facile and unsatisfying conclusions. Recent publications such as William Cronon's Nature's Metropolis (1991) focus directly on the Midwest and explore the complex relationships that were established on a regionwide basis. Cronon's study examines the intricate ties that bound nineteenth-century Chicago as much to the cattle ranches of Sweetwater County, Wyoming, as to the meatpackers of Sioux City, Iowa, or to the stumpage holders of northern Wisconsin. When viewed in this context, midwesterners are revealed in a far richer, more complex, and more satisfying fashion.

Although it could have been made more useful by the inclusion of a thorough bibliography, Iowa: The Middle Land nevertheless is a good new research tool for public historians working to make Iowa's history more accessible. The book also serves as a clear invitation for all students of Iowa and midwestern history, on or off campus, to actively engage in the dialogue about how to define and understand this region of the country.

\section{LYNN E. NIELSEN}

Dorothy Schwieder opens chapter seven of Iowa: The Middle Land, her account of the history of religious and educational institutions in Iowa, by stating, "From territorial days to the 
present, Iowans have been particularly proud of their schools and churches" (109). Clearly, education is one of the major foundations upon which Iowans have built a national reputation and around which Iowa's many villages have built a sense of local identity and community pride. The results of SAT and ACT tests suggest that Iowans do an excellent job of teaching their children everything from geometry to geography. Teaching their children the history of their home state, however, has often suffered neglect. The "sense of moderation" Schwieder identifies in her preface may partly account for this. Iowans have never been known for their excesses. Although this quality has served the state well in maintaining a sense of equilibrium during periods of economic or social stress, its application to the transmission of Iowa's history is a liability rather than an asset.

Because Iowans suffer from collective low self-esteem, the manner in which Iowa's history is presented to students in the state's elementary and secondary classrooms varies widely. Iowa history is a required element of the curriculum for Iowa's public schools, but there is little evidence that upon graduation students know and appreciate their state's history. Iowa history is often taught poorly as a grab-bag collection of disconnected historical trivia, irrelevant to the lives of students or teachers.

For nearly twenty years, I have presented teacher workshops on Iowa history. A few of the teachers who attend have made Iowa history a matter of individual interest and have committed considerable personal and institutional resources toward the development of curricula that stimulate and motivate students to appreciate and understand the history of their state. A much larger number, however, accept the responsibility for teaching Iowa history with little more than a few copies of an outdated textbook and a "good luck" from an administrator. Data from recent teacher surveys suggest that while most teachers of Iowa history are committed to the ideals of high quality teaching, most lack access to college level courses on Iowa history, infrequently attend professional workshops on Iowa history, and lack effective teaching materials. Schwieder's book represents a hope that this situation need not continue and that improvements can be made in the quality of Iowa history instruction. 
How then can Iowa: The Middle Land help elevate the level of Iowa history instruction in Iowa's elementary classrooms? How will students of Iowa history in high school classes find the book useful? How will Iowa history teachers in continuing education classes benefit from this book? Two major strengths of Schwieder's work support the quality of Iowa history teaching for the many students and teachers of Iowa history throughout the state.

First and foremost, Schwieder models excellence in the craft of writing history. As a gifted storyteller, she never loses sight of the story line while reconstructing the past. History instruction at its worst, a disjointed and disconnected collection of isolated facts and terms, denies learners a comprehensible and connected picture of the past, which requires a sense of story. Schwieder captures snapshots of the past and carefully arranges them to make Iowa's story accessible and understandable for readers while providing a model for teachers of Iowa history.

The craft of writing history is further extended in the way Schwieder has structured the book. The story she tells is carried on strong conceptual ideas and logical organization. The title itself captures the foundational concept of the book: Iowa in the middle, socially, economically, geographically, chronologically, and politically. In addition, each chapter begins with a brief summary of the major ideas supporting the chapter material, the historical context of the events, or an interpretation of a historical period from the perspective of those who remembered it. For example, in chapter fifteen, "World War II and the Years Beyond," Schwieder introduces readers to the international significance of the war and its importance as an economic and social divide between the world lowans knew in the late 1930s and the world they would come to know in the years beyond. With this introduction, the story of World. War II unfolds as international events become local through the words of people who remembered them.

The craft of writing history is also carried forward in the clear, precise, and readable style in which Schwieder writes. While she frequently cites facts and statistics to support a concept, she uses this data as a device to extend the story, never allowing the material to become over-complicated, impersonal, 
or too abstract. As a result, neither the story nor the reader gets lost in intricate historical detail. For example, in chapter three, "Pioneers on the Prairie," Schwieder uses Iowa population data from 1836 to 1846 to support the concept that settlement occurred rapidly on the prairie. That statistical data, however, is framed by rich and interesting material detailing the pioneer experience of the Savage family, who settled in Henry County in the $1850 \mathrm{~s}$.

The selection and organization of historical content is a second major strength of Schwieder's work. Although readers will need to look elsewhere for information on Iowa's prehistory and geological past, Schwieder carefully and selectively covers Iowa's social and economic history from early Native Americans to the 1990s. From an instructional perspective, a significant strength of the book is its full chronology of Iowa history. With this book in hand, teachers and students have at their disposal the big picture of Iowa's history, including the third and final section devoted to the decades since the Great Depression, the point at which other authors have concluded.

Another major strength of the book is its emphasis on social history. Because it is organized around strong conceptual ideas, the reader is provided both a micro and macro view of Iowa's history. Major generalizations about Iowa's past are carried forward on the stories of individuals whose voices illuminate those ideas. For example, Schwieder opens chapter eleven, "Cultural Diversity," by summarizing the major concepts related to immigration and the diversification of Iowa's population during the time (1880-1920) when Iowa became home to great waves of new Americans. As the stories pour from the pages of this chapter, readers are introduced to the outspoken Rev. Wilhelm Schumann, a German-American Lutheran minister who was accused of interfering with the war effort during World War I and later imprisoned; John Corso, an Italian immigrant who, at the age of sixteen, worked in the coal mines near Hocking; Antonia Cerato, an Italian-American who helped support her family by boarding young Italian immigrants; Marjorie Brown, who lived as a young girl in the relative racial utopia of Buxton, an early coal mining town with a significant African-American population; and Frances Puente, who recalls the strong religious 
traditions of the Mexican-American community near Bettendorf where he grew up.

Schwieder herself clearly lays out the strengths and limitations of her book in the preface. Iowa: The Middle Land is a social and economic history of the state. It is not a political history. In that regard, Schwieder makes no attempt to claim the text as a comprehensive history of the Hawkeye state. It would take no less than four volumes to provide that.

Iowa: The Middle Land offers students and teachers of Iowa history a conceptual picture of Iowa supported by the voices of individuals whose lives formed the tapestry of Iowa's past. In that regard, the book not only models the craft of historical writing at its best, but also provides students and teachers of Iowa history with the content of history at its finest.

\section{WALLACE HETTLE}

The first time I taught Iowa history, I ventured to ask one particularly bright student what she thought of the course. "Well," she replied, "the lectures are interesting but I don't see how they all fit together." Without realizing it, this student pointed out a serious problem: "fitting together" diverse materials into a coherent synthesis is, after all, essential for teachers who want their students to develop a general understanding of the past as a process of continuity and change over time.

I resolved to do better at providing my students a unified picture of Iowa history, but making it all "fit together" in the classroom continues to be a challenge. One difficulty for teachers has been the relative lack of scholarly reflection on the whole range of Iowa history. Iowa historiography has consisted of an abundance of articles and monographs on varied topics - as a set of fragments, like puzzle pieces waiting for someone to put them together. And we must put them together: in spite of trendy complaints about the difficulties of grand historical narratives, good teachers know that only broad synthesis of diverse themes and events makes the past come alive for students. When scholars have yet to produce a unified understanding of a topic, teachers must improvise and draw links between the issues to further the goal of historical understanding. 
Dorothy Schwieder has been exploring how the pieces of Iowa history fit together for the past twenty-five years while teaching at Iowa State University. Now, she is sharing her insights derived from both teaching and scholarship in her new survey of Iowa history, Iowa: The Middle Land. The arrival of this book is a welcome development for teachers of Iowa history. Schwieder's comprehensive work is written in an accessible style that will make it a good survey textbook for classes on Iowa history.

Other surveys of Iowa history have been written in the past. The best of them, Leland Sage's History of Iowa, was published more than twenty years ago. Sage studied Iowa political history, taught Iowa history, and supervised numerous master's theses in the field. His useful book focused mostly on political history. In the ensuing years, fields such as social, cultural, labor, and women's history have grown. These newer studies have enriched Iowa historiography, but, paradoxically, pose a challenge for teachers of Iowa history. Iowa history is more inclusive than it was several decades ago, and it is also more complex. When teaching Iowa history, the goal should be not only to convey the diverse range of experience in the past, but also to reveal the shared heritage that makes Iowans think of our state as a place with a distinctive identity.

Schwieder explores Iowa's diversity and unity in three distinct sections. The first four chapters, labeled "the early years," explore traditional topics such as the expropriation of Native American land, early frontier settlement, the rise of the Republican Party in the 1850s, and the Civil War. In this opening section, Schwieder wisely eschews extended discussion of land forms, archeology, and prehistoric times. This omission signals the author's intention to make this work accessible: the book steers away from arcane matters such as pot shards. Teachers will need to clarify the limitations of this approach: students must be reminded that "history," which is defined by the interpretation of written sources, covers only a relatively short period of Iowa's existence.

The great virtue of the book emerges in the beginning chapters: Schwieder makes complex issues easily comprehensible. She ably covers the political jockeying of the territorial period 
and the politics of statehood. But social history is the strength of this book, as becomes clear in chapters three and four, "Pioneers on the Prairie" and "Economic Development in the Nineteenth Century." Schwieder skillfully interweaves concise discussion of dry but important topics such as railroad land grants and the Preemption Act of 1841 with individual stories in which the settlement of the frontier emerges as a lived experience. Apt examples and quotations from both primary and secondary sources enrich the discussion, but she does not neglect the economic and political complexity of events. Schwieder's adept balancing of political process and human stories is just right for a classroom text. Readers get more than a synthesis of the available monographs, which might satisfy scholars; they also get a good read, which is something students deserve.

Sustained attention to "diversity" marks another merit for using this book in the classroom. Schwieder sees Iowa history as the story of a spectrum of people crossing divisions of race, class, ethnicity, and gender. Such attention to people who fell outside the rubric of old-fashioned political history is crucial to the classroom teacher. Today's students come from a variety of backgrounds, and some come to class skeptical about the value of history. Many still worry that courses will be defined only by memorization of the names of laws and leaders. This book will help teachers offer much more.

For Schwieder, the diversity of Iowans' experience is not tacked on to the book as an afterthought or as a nod to "political correctness," but integrated into the book in a way that enriches our understanding of traditional topics. For example, chapter six, "Cultural Diversity," draws on recent scholarship in African-American history that is crucial for understanding traditional topics such as the rise of the Republican Party. Moreover, Schwieder's close attention to immigration and "cultural pluralism" in the nineteenth and early twentieth centuries will help students assess today's debates about multiculturalism. In exploring diversity, Schwieder's book stands apart from previous histories of the state and meshes with teachers' need to connect with students from a variety of backgrounds.

The book is most thorough, and most exciting, when Schwieder discusses "The Middle Years" from the 1870 s to the 
1930s. The controversies of this time, ranging from prohibition to agricultural parity, are recounted in an engaging fashion. The success of this section should not be surprising. This period has received much recent attention from researchers, and Schwieder draws on the work of these scholars. Although the historiography for the period after 1940 is extremely thin, Schwieder valiantly follows the story until the $1990 \mathrm{~s}$. This is important, because for students today, the farm crisis of the 1980 s and the advent of legalized gambling are distant events known only secondhand.

Schwieder acknowledges her debts to other Iowa historians in the text. Although this is gracious, students may find frequent references to historians distracting: for example, Leland Sage is mentioned at least fourteen times in the text. Such references to historiography would be better left to the endnotes.

Iowa: The Middle Land lacks the bells and whistles one sees in U.S. history or western civilization textbooks: there are no sidebars, photo essays, or review questions. That is not necessarily a bad thing. This book is for a limited market, and students and school districts uniformly prefer affordability to color illustrations. Moreover, the straightforward, primarily thematic organization of the text will facilitate classroom discussion.

This book will serve well as an Iowa history textbook for many years to come. The book is extremely accessible by college standards, and should also work in high school classrooms. Schwieder's up-to-date treatment of events and her mastery of recent scholarship makes the publication of Iowa: The Middle Land a welcome, indeed exciting, development for teachers of Iowa history. 
Copyright of Annals of Iowa is the property of State of Iowa, by \& through the State Historical Society of Iowa and its content may not be copied or emailed to multiple sites or posted to a listserv without the copyright holder's express written permission. However, users may print, download, or email articles for individual use. 